\title{
Prostaglandin $\mathbf{F}_{2 \alpha}$ Negatively Regulates Bone Resorption in Murine Osteoclast Development ${ }^{1}$
}

\author{
M. Kamon ${ }^{\text {a }}$ D. Fujita ${ }^{\text {a }}$ N. Goto ${ }^{\text {a }}$ H. Amano ${ }^{\text {, }}$, and K. Sakamoto ${ }^{\text {a,* }}$ \\ ${ }^{a}$ Graduate School of Life and Environmental Sciences, University of Tsukuba, 1-1-1 \\ Tennoudai, Tsukuba, Ibaraki 305-8572, Japan, and ${ }^{b}$ Department of Pharmacology, \\ School of Dentistry, Showa University, 1-5-8, Hatanodai, Shinagawaku, Tokyo \\ 142-8555, Japan \\ *Correspondence to: Kazuichi Sakamoto, Graduate School of Life and Environmental \\ Sciences, University of Tsukuba, 1-1-1 Tennoudai, Tsukuba, Ibaraki 305-8572, Japan, \\ Tel. and Fax: +81-29-853-4875; E-mail: sakamoto@biol.tsukuba.ac.jp \\ ${ }^{1}$ This work was supported in part by Grants-in-Aid for Scientific Research from the \\ Ministry of Education, Science, Sports, and Culture of Japan.
}




\section{SUMMARY}

Prostaglandin (PG) $\mathrm{E}_{2}$ promotes osteoclastic cell differentiation, but the physiological function of $\mathrm{PGF}_{2_{\alpha}}$ remains unclear. We examined the physiological effects of $\mathrm{PGF}_{2_{\alpha}}$ on osteoclast differentiation using a murine cell line, RAW264, and the column-purified murine bone marrow cells, both of which are differentiable into osteoclast-like multi-nuclear cells. Although $\mathrm{PGF}_{2_{\alpha}}$ did not affect the number of differentiated osteoclasts, $\mathrm{PGF}_{2_{\alpha}}$ reduced the bone resorption activity of osteoclasts developed from both cell types in a pit formation assay. Thus, $\mathrm{PGF}_{2_{\alpha}}$ inhibits bone resorption without affecting the number of osteoclasts, providing a novel molecular mechanism underlying bone metabolism. 


\section{INTRODUCTION}

In vertebrates, bone regulates blood $\mathrm{Ca}^{2+}$ levels by storing intravital $\mathrm{Ca}^{2+}$, as well as providing somatic support. Bone undergoes repeated resorption by osteoclasts and formation by osteoblasts. Bone disease arises when the metabolic balance between bone resorption and bone formation collapses. For example, excessive bone resorption from a postmenopausal lack of estrogen causes osteoporosis ${ }^{1}$. Bone diseases related to aging, such as geriatric osteoporosis, are becoming large social problems. Therefore, clarifying the mechanisms involved in bone metabolism is extremely important.

Osteoblast activity is important for osteoclast development ${ }^{2,3}$. The osteoclast differentiation-inducing factor, receptor activator of nuclear factor $\kappa B$ ligand (RANKL) is expressed on the osteoblast cell membrane and acts on osteoclast precursor cells to induce osteoclast development ${ }^{4,5}$. RANKL also promotes the survival of differentiated osteoclasts ${ }^{6}$. Colony stimulating factor-1 (CSF-1), which is secreted by osteoblasts, is also required for osteoclast differentiation and survival ${ }^{7-9}$. Prostaglandin (PG) $\mathrm{E}_{2}$, parathyroid hormone, and activated vitamin D3 also promote osteoclast differentiation ${ }^{3,}$ 10. These molecules induce RANKL cell-surface expression in osteoblasts to promote osteoclast differentiation. However, $\mathrm{PGE}_{2}$ can also act directly on $\mathrm{PGE}_{2}$ receptors in osteoclasts to promote differentiation ${ }^{11,12}$.

Four subtypes of $\mathrm{PGE}_{2}$ receptors, EP1, EP2, EP3, and EP4, transmit signals by coupling with different $\mathrm{G}$ proteins ${ }^{13}$. EP2 and EP4 promote cyclic adenosine monophosphate (cAMP) production by coupling with Gs protein, whereas EP3 inhibits cAMP production by coupling with Gi. EP1 causes elevations in intracellular $\mathrm{Ca}^{2+}$ by coupling with $\mathrm{Gq}^{13}$. Osteoclasts express all $\mathrm{PGE}_{2}$ receptors, and production of intracellular $\mathrm{Ca}^{2+}$ through EP1 or production of cAMP and activation of protein kinase A (PKA) through EP2 or EP4 are critical for osteoclast cell differentiation 11, 12, 14, 15.

PGs are lipid mediators that regulate a number of physiological functions. $\mathrm{PGE}_{2}$ promotes the resorption of bone, and $\mathrm{PGI}_{2}$ inhibits osteoclastic bone resorption, suggesting that PGs are critically important in bone metabolism ${ }^{16,17,18}$. Although there were a couple of reports that $\mathrm{PGF}_{2_{\alpha}}$ acted on the bone metabolism in organ and osteoblasts $^{19,20}$, little is known about the physiological roles in osteoclast development.

$\mathrm{PGF}_{2 \alpha}$ signals through a specific receptor $(\mathrm{FP})^{13,21}$. FP activation stimulates Gq, leading to phosphatidylinositol hydrolysis by phospholipase $\mathrm{C}$ to produce 
diacylglycerol (DAG) and inositol 1,4,5-trisphosphate $\left(\mathrm{IP}_{3}\right)^{22,} 23 . \mathrm{IP}_{3}$ stimulates intracellular $\mathrm{Ca}^{2+}$ release and DAG activates protein kinase $\mathrm{C}(\mathrm{PKC})$. Nuclear factor of activated T cell c1 (NFATc1) is the master regulator of osteoclast differentiation ${ }^{24,25}$, and requires a $\mathrm{Ca}^{2+}$ signal for activation. Since $\mathrm{PKC}$ also contributes to osteoclast differentiation, $\mathrm{PGF}_{2_{\alpha}}$ activity may be involved in this process ${ }^{26,27}$.

In this study, we clarified the physiological effects of $\mathrm{PGF}_{2_{\alpha}}$ on osteoclast development using both a murine RAW264 cell line and the primary bone marrow cells that can differentiate into osteoclast-like multi-nuclear cells (MNC).

\section{MATERIALS AND METHODS}

\subsection{Expression plasmid}

The expression plasmid (pGEX-2TK-RANKL) for the soluble RANKL-GST fusion protein was a gift from Dr. Takeya at the University of Nara Institute of Science and Technology 28,29 .

\subsection{Cell culture}

RAW264 cells (RIKEN Institute of Physical and Chemical Research cell bank, Tsukuba, Ibaraki, Japan) were cultured at $37^{\circ} \mathrm{C}$ in $90-\mathrm{mm}$ dishes in Dulbecco's modified Eagle's medium (DMEM) (Sigma-Aldrich, St. Louis, MO, USA) supplemented with 10\% FBS (Sanko Junyaku, Chiyoda, Tokyo, Japan) and 1\% MEM non-essential amino acid solution (NEAA) (Invitrogen, Carlsbad, CA, USA). We obtained mouse myeloid cells from femurs and tibiae resected from a 6-week-old male mouse (Saitama Experimental Animal Supply, Katsushika, Saitama, Japan). According to the methods of Ly and Mishell, myeloid cells were purified using a Sephadex-G10 (GEC, Fairfield, CT, USA) column, and the obtained cell population was used for further analysis ${ }^{30,31,32}$.

\subsection{Preparation of GST-RANKL}

The pGEX-2TK-RANKL plasmid, which includes an active RANKL construct, was transfected into E. coli JM109. Transduced E. coli were cultured at $37^{\circ} \mathrm{C}$ in $1 \mathrm{~L}$ Super Broth culture medium (25 g/L Trypton Pepton [Becton, Dickinson and Co., Franklin Lakes, NJ, USA], $15 \mathrm{~g} / \mathrm{L}$ Bacto Yeast Extract [Becton, Dickinson], $5 \mathrm{~g} / \mathrm{L} \mathrm{NaCl}$ ) with 50 
$\mu \mathrm{g} / \mathrm{mL}$ ampicillin sodium until the $\mathrm{OD}_{600}$ was about 0.75 . Expression of GST-RANKL was induced by incubating for $8 \mathrm{~h}$ with $0.25 \mathrm{mM}$ isopropyl- $\beta$-D-thiogalactopyranoside at $18{ }^{\circ} \mathrm{C}^{28,29}$.

After centrifuging of the E. coli solution at $3000 \times \mathrm{g}$ at $4{ }^{\circ} \mathrm{C}$ for $10 \mathrm{~min}$, the E. coli were resuspended in NETN buffer $(20 \mathrm{mM}$ Tris $\cdot \mathrm{HCl}$ [pH 8.0], $100 \mathrm{mM} \mathrm{NaCl}, 1 \mathrm{mM}$ EDTA, 0.5\% NP-40) and disrupted with a Supersonicator. This solution was separated by 2 nd centrifugation again, and Glutathione Sepharose $4 \mathrm{~B}$ beads (GEC) were added to the supernatant, and then the mixture was incubated at $4{ }^{\circ} \mathrm{C}$ for $8 \mathrm{~h}$ in a rotary mixer. After washing of the beads in PBS four times, $500 \mu \mathrm{L}$ of glutathione-NaCl buffer $(100$ $\mathrm{mM}$ Tris $\cdot \mathrm{HCl}$ [pH 8.0], $120 \mathrm{mM} \mathrm{NaCl}, 20 \mathrm{mM}$ glutathione [Wako Pure Chemical, Osaka, Japan]) was added, and the mixture was incubated at $4{ }^{\circ} \mathrm{C}$ for $2 \mathrm{~h}$ to elute the GST-RANKL solution. The eluate was mechanically sterilized with a $0.2-\mu \mathrm{m}$ filter (Toyo Roshi, Taitou, Tokyo, Japan), and endotoxin was removed using Detoxi-Gel Endotoxin Removing Gel (Pierce Biotechnology, Rockford, IL, USA) ${ }^{28,} 29$.

\subsection{In vitro osteoclast development}

RAW264 cells were plated on a 96-well plate at $2 \times 10^{3}$ cells/well and cultured in Minimum Essential Medium Alpha Medium ( $\alpha$-MEM) (Invitrogen) (10\% FBS, $1 \%$ NEAA) containing $100 \mathrm{ng} / \mathrm{mL}$ RANKL and $\mathrm{PGF}_{2 \alpha}$ (Wako). Cells were used after 5-d culture.

The column-purified bone marrow cells were plated at $1 \times 10^{5}$ cells/well on a 96-well plate coated with RANKL (final $100 \mathrm{ng} / \mathrm{mL}$ ) and CSF-1 (final $20 \mathrm{ng} / \mathrm{mL}$ ). Inoculated cells were cultured in $\alpha$-MEM $(10 \% \mathrm{FBS})$ containing $\mathrm{PGF}_{2_{\alpha}}$ or fluprostenol (Sigma-Aldrich), and cells were collected $7 \mathrm{~d}$ later for further analysis.

\subsection{TRAP assay}

Wells were washed with PBS, and cells were fixed by incubation with $100 \mu \mathrm{L}$ of $4 \%$ paraformaldehyde at $4{ }^{\circ} \mathrm{C}$ overnight. Each well was washed with distilled water, and then $100 \mu \mathrm{L}$ of tartrate-resistant acid phosphatase (TRAP) solution (50 mM sodium tartrate, $45 \mathrm{mM}$ sodium acetate $[\mathrm{pH} 5.0], 0.01 \%$ naphthol AS-MX phosphate [Sigma-Aldrich], $0.03 \%$ fast red violet LB salt [Sigma-Aldrich]) was added to each well and incubated for $10 \mathrm{~min}^{33}$. Cells were washed with water and observed through an optical microscope. 


\subsection{Acridine orange staining}

After cell differentiation, acridine orange (Merck, Whitehouse Station, NJ, USA) was added to a final concentration of $5 \mu \mathrm{g} / \mathrm{mL}$, and cells were cultured for $30 \mathrm{~min}$. Stained cells were observed through a fluorescence microscope ${ }^{34,35}$.

\subsection{Pit formation assay}

We dismembered the small ivory column with a diameter of $4 \mathrm{~mm}$ (Atelier Sugimoto, Musashino, Tokyo, Japan) to obtained thin dentin slices, which were polished with glass paper and abrasives to $0.3-\mu \mathrm{m}$ thickness, then washed with a supersonicator. These slices were put in 48-well plates, $100 \%$ EtOH was added, and the dentin was dried with a UV lamp on a clean bench. The dried slices were placed in a 24-well plate with a few drops of FBS. The slices were soaked for several hours in $\alpha$-MEM, then the medium was removed, and RAW264 cells were plated on the slices at $5 \times 10^{3}$ cells/well in $\alpha$-MEM media containing $100 \mathrm{ng} / \mathrm{mL}$ RANKL and PGF $2_{\alpha}$. After 3, 5,7 , and $9 \mathrm{~d}$ in culture, culture medium was replaced; dentin slices were collected after 11-d culture.

The column-purified bone marrow cells were spread at $2.5 \times 10^{5}$ cells/well on dentin slices coated with RANKL (final $100 \mathrm{ng} / \mathrm{mL}$ ) and CSF-1 (final $20 \mathrm{ng} / \mathrm{mL}$ ). Cells were cultured in $\alpha$-MEM containing PGF $_{2 \alpha}$, with medium changes after 2, 5, and $7 \mathrm{~d}$; dentin slices were collected after $9 \mathrm{~d}$ incubation.

After culturing, dentin slices were collected and soaked in $0.1 \%$ ammonia at $4{ }^{\circ} \mathrm{C}$ overnight. Cells were removed from the dentin slices with a supersonicator, and the slices were dehydrated by $70 \%$ to $99 \%$ ethanol, dried, and coated with carbon. Microscopic examination was performed with a scanning electron microscope.

\subsection{PCR analysis}

RAW264 cells were cultured on $60 \mathrm{~mm}$ plates, and RNA was extracted by a standard acid-GTC-phenol extraction method ${ }^{11}$. The cDNA from RAW264 cells was synthesized using M-MLV Reverse Transcriptase (Takara Bio, Otsu, Shiga, Japan). The cDNA of the column-purified bone marrow cells was also used for PCR analysis. PCR $\left(95^{\circ} \mathrm{C}\right.$ for $5 \mathrm{~min} ; 18-40$ cycles of $95^{\circ} \mathrm{C}$ for $30 \mathrm{~s}, 55^{\circ} \mathrm{C}$ for $1 \mathrm{~min}, 72^{\circ} \mathrm{C}$ for $1 \mathrm{~min}$; $72{ }^{\circ} \mathrm{C}$ for $7 \mathrm{~min}$ ) was performed using the following primers: 
Glyceraldehyde 3-phospate dehydrogenase (G3PDH) primers:

G3PDH-S1 (5'-GACCCCTTCATTGACCT-3')

G3PDH-A1 (5'-CCACCACCCTGTTGCTGT-3')

$\mathrm{PGF}_{2_{\alpha}}$ receptor $(\mathrm{FP})$ primers:

MFP-S1 (5'-AGTCAAAGGCTTCCTTCC-3')

MFP-A1 (5'-GTGACGGCATTGCACGAG-3')

Catepsin $\mathrm{K}(\mathrm{CtpK})$ primers:

mhCtpK-S2 (5'-TCCATACATATGAACTGG-3')

mhCtpk-A2 (5'-TATCCTTTGTTTCCCCAG-3')

Calcitonin receptor $(\mathrm{CtR})$ primers:

mCTR-S1 (5'-CGAACCTGGTCCAACTATAC-3')

mCTR-A1 (5'-CTTCACAGCCTTCAGGTACA-3')

Tartrate-resistant acid phosphatase (TRAP) primers:

mTRAP-S1 (5'-CGGGAAATGGCCAATGCCAA-3')

mTRAP-A1 (5'-TAGGCAGTGACCCCGTATGT-3')

Matrix metalloproteinase 9 (MMP9) primers:

mMMP9-S1 (5'-CTGTCCAGACCAAGGGTACAGCCT-3')

mMMP9-A1 (5'-GAGGTATAGTGGGACACAT-3')

Nuclear factor of activated T cell c1 (NFATc1) primers:

mNfatC1-S1 (5'-CAACGCCCTGACCACCGATAG-3')

mNfatC1-A1 (5'-GGCTGCCTTCCGTCTCATAGT-3')

Receptor activator of nuclear factor $\kappa \mathrm{B}$ (RANK) primers:

mRANK-S1 (5'-TGTTGCAGCAGATGCGAA-3')

mRANK-A1 (5'-TCTTGCTGACTGGAGGTT-3')

\subsection{Western blotting}

Cells were dissolved in sample buffer $(50 \mathrm{mM}$ Tris $\cdot \mathrm{HCl}$ [pH 6.8], 2\% SDS, 6\% $\beta$-mercaptoethanol, $1 \mathrm{mM} \mathrm{Na} \mathrm{VO}_{4}, 1 \mathrm{mM} \mathrm{NaF}, 1 \mathrm{mM}$ PMSF, $1 \mathrm{mM}$ EDTA) with a supersonicator. SDS-PAGE was performed with $20 \mu \mathrm{g}$ of protein, and the separated proteins were transferred to a nitrocellulose membrane. The blotted membrane was soaked in 5\% BSA and incubated with primary antibody for phosphorylated PKC (phospho-PKC [pan] [Cell Signaling Technology, Danvers, MA, USA], phospho-PKC $\alpha / \beta_{\text {II }}$ [Cell Signaling Technology], phospho-PKCס [Cell Signaling 
Technology], $\beta$-actin [SIGMA-Aldrich]), and with a secondary antibody for HRP-conjugated anti-rabbit IgG (Cell Signaling Technology). Phospho-PKC (pan) detects phosphorylated PKC $\alpha, \quad \mathrm{PKC} \beta_{\mathrm{I}}, \mathrm{PKC} \beta_{\mathrm{II}}, \mathrm{PKC} \delta, \mathrm{PKC} \varepsilon$, and PKC $\eta$. Phospho-PKC $\alpha / \beta_{\text {II }}$ detects phosphorylated PKC $\alpha$ and PKC $\beta_{\text {II. }}$ Phospho-PKC $\delta$ detects phosphorylated PKCס. Finally, each protein band was detected by chemiluminescence (Las1000, FujiFILM, Minato, Tokyo Japan).

\subsection{Image analysis}

Image analysis was performed using ImageJ, a public domain Java-based image-processing program inspired by NIH Image ${ }^{36}$.

\subsection{Statistical analysis}

Results are expressed as mean \pm standard deviation. Comparisons between groups were made by analysis of variance (ANOVA), and when significant, were examined by Tukey's all-pairwise-comparison test. Differences were considered significant when $P<$ 0.05. Statistical analysis was performed using Excel 2004 (Microsoft, Redmond, WA, USA) with the add-in software Statcal $2^{37}$.

\section{RESULTS}

3.1. $\mathrm{PGF}_{2_{\alpha}}$ influences osteoclast development of the column-purified bone marrow cells

We examined murine myeloid cells to determine how $\mathrm{PGF}_{2_{\alpha}}$ influenced osteoclast differentiation under in vivo-like conditions. Mouse bone marrow was resected, and cells were purified by passage through a G-10 column. The column-purified cells were cultured for $7 \mathrm{~d}$ with various concentrations of $\mathrm{PGF}_{2 \alpha}$ in the presence of $100 \mathrm{ng} / \mathrm{mL}$ RANKL and $20 \mathrm{ng} / \mathrm{ml} \mathrm{CSF-1,} \mathrm{leading} \mathrm{to} \mathrm{osteoclast} \mathrm{development.} \mathrm{Induced} \mathrm{osteoclasts}$ were specifically dyed by the TRAP method, and the number and size of stained osteoclast-like MNC with more than three nuclei were measured (Figs. 1A, B, C). $\mathrm{PGF}_{2_{\alpha}}$ did not change the number of developed osteoclast (Fig. 1B). $\mathrm{PGF}_{2_{\alpha}}$ reduced the area occupied by osteoclast (Fig. 1C). Furthermore, an expression of FP in the column-purified bone marrow cells was examined by RT-PCR. As shown in Fig. 1D, mRNA of FP was expressed significantly, in both pre- and post-osteoclast 
differentiation. We further examined the physiological action of $\mathrm{PGF}_{2_{\alpha}}$ to osteoclast development by using fluprostenol, a selective FP agonist. As shown in figure, Fluprostenol slightly reduced the number of MNC (Fig. 1E) and reduced the area occupied by osteoclast to $40 \%$ (Fig. 1F).

3.2. $\mathrm{PGF}_{2_{\alpha}}$ affects the function of the differentiated column-purified bone marrow cells

We also examined whether $\mathrm{PGF}_{2_{\alpha}}$ modified pit formation by using osteoclast developed from the column-purified bone marrow cells. Purified myeloid cells were cultured on dentin slices for $7 \mathrm{~d}$ in the presence of $20 \mathrm{ng} / \mathrm{mL} \mathrm{CSF}-1,100 \mathrm{ng} / \mathrm{mL}$ RANKL, and various doses of $\mathrm{PGF}_{2 \alpha}$. After differentiation, cells were cultured for 2 more $\mathrm{d}$ with $\mathrm{PGF}_{2_{\alpha}}$ to let pit formation proceed on dentin slices. $\mathrm{PGF}_{2_{\alpha}}$ dose-dependently reduced the size of the pit on the dentin slice formed by myeloid-derived osteoclasts (Figs. 2A, 2B). In the acridine orange assay, $\mathrm{PGF}_{2_{\alpha}}$ did not modulate acid accumulation in osteoclast lysosomes (Fig. 2C).

\section{3. $\mathrm{PGF}_{2 \alpha}$ influences to osteoclast-like development of RAW264 cell}

We next used RAW264 cell that is mouse macrophage-derived cell line. RAW264 cell differentiates into osteoclast-like MNC in the presence of RANKL ${ }^{29}$. We added $\mathrm{PGF}_{2 \alpha}$ to RAW264 cells in the presence of $100 \mathrm{ng} / \mathrm{mL}$ RANKL, and after $5 \mathrm{~d}$ culture, differentiated osteoclasts were detected by TRAP staining.

Microscopic observation revealed that $\mathrm{PGF}_{2_{\alpha}}$ dose-dependently increased the size of large $\mathrm{MNC}$ (Fig. 3A). As in myeloid cells, $\mathrm{PGF}_{2_{\alpha}}$ did not affect the total number of MNC (Fig. 3B). But $10^{-8} \mathrm{M} \mathrm{PGF}_{2_{\alpha}}$ increased the surface area covered by MNC three-fold ,in contrast to myeloid cells (Fig. 3C).

\section{4. $\mathrm{PGF}_{2 \alpha}$ affects the function of differentiated RAW264 cell}

We also examined whether $\mathrm{PGF}_{2_{\alpha}}$ affected bone resorption in differentiated RAW264 cell using the pit formation assay. $\mathrm{PGF}_{2_{\alpha}}$ was added to dentin slices in the presence of $100 \mathrm{ng} / \mathrm{ml}$ RANKL for $11 \mathrm{~d}$ to induce osteoclast development. As in myeloid cells, $\mathrm{PGF}_{2 \alpha}$ dose-dependently decreased pit area (Fig. 4A, B). Also as in myeloid cells, $\mathrm{PGF}_{2 \alpha}$ did not affect lysosomal $\mathrm{H}^{+}$levels in RAW264 cell (Fig. 4C).

\subsection{FP expression and signal transduction in RAW264 cell}


We examined whether FP mRNA was expressed in either naive RAW264 cell or MNC derived from them. Cells were cultured in the presence or absence of RANKL and $\mathrm{PGF}_{2 \alpha}$ for 1,5 , or $11 \mathrm{~d}$, and RNA prepared from these cells was subjected to RT-PCR. FP mRNA was expressed throughout the incubation period (Fig. 5A).

We then examined whether FP signaling (measured by PKC phosphorylation) was activated by $\mathrm{PGF}_{2_{\alpha}}$. RAW264 cells were cultured for $24 \mathrm{~h}$ in the presence or absence of $100 \mathrm{ng} / \mathrm{mL}$ RANKL, and then exposed to $\mathrm{PGF}_{2_{\alpha}}$ for $30 \mathrm{~min}$. $\mathrm{PGF}_{2_{\alpha}}$ dose-dependently increased levels of phosphorylated PKC $\alpha, P K C \beta_{\Pi}$, and $\mathrm{PKC} \delta$ in the presence of RANKL (Fig. 5B).

3.6. $\mathrm{PGF}_{2 \alpha}$ does not influence the expression of osteoclast specific genes

We examined the effects of $\mathrm{PGF}_{2_{\alpha}}$ on the expression of mRNAs for osteoclast-specific genes by RT-PCR. RAW264 cells were differentiated into osteoclasts by the addition of $\mathrm{PGF}_{2_{\alpha}}$ and $100 \mathrm{ng} / \mathrm{mL}$ RANKL, and RNA was prepared from cells cultured for $1,3,5$, or $7 \mathrm{~d}$. $\mathrm{PGF}_{2_{\alpha}}$ did not change mRNA levels of the osteoclast specific genes cathepsin $\mathrm{K}(\mathrm{CtpK})$, calcitonin receptor (CtR), Tartrate-resistant acid phosphatase (TRAP), Matrix metalloproteinase 9 (MMP9), or Nuclear factor of activated T cell c1 (NFATc1), Receptor activator of nuclear factor $\kappa \mathrm{B}$ (RANK) (Fig. 6).

\section{DISCUSSION}

Generally, it is known that $\mathrm{PGE}_{2}$ acts on osteoblasts and induces an expression of RANKL, leading to a strong promotion osteoclast development and bone resorption ${ }^{10}$. In addition, Fujita et al ${ }^{11}$ reported that $\mathrm{PGE}_{2}$ directly acts on osteoclast progenitor cell too and promotes osteoclast cell differentiation. In this report, we revealed that $\mathrm{PGF}_{2_{\alpha}}$ acts on precursor osteoclasts or on osteoclasts directly and has the opposite physiological function of $\mathrm{PGE}_{2}$ in osteoclast.

As it was reported by Fujita et al ${ }^{11}$, mouse myeloid cells, from which an adhesive cell were removed using a G10 column ${ }^{30}$, were used for the physiological analysis. Myeloid cells include stromal cells, macrophages, and blood corpuscle cells, but macrophages and stromal cells, which include osteoblasts and their precursors, are removed by passing through a G10 column ${ }^{31,32}$. Because the hematopoietic stem-cells, 
which are the potential precursor of osteoclast, were included in the column-purified myeloid cells fraction, osteoclast differentiation from these cells is easily induced by the stimulation of RANKL and CSF-1. Experiment using the column-purified myeloid cells revealed that $\mathrm{PGF}_{2 \alpha}$ reduced the size of $\mathrm{MNC}$ (Fig. 1A), but did not increase the total number of $\mathrm{MNC}$ with three or more nuclei (Fig. 1B). Thus, $\mathrm{PGF}_{2_{\alpha}}$ reduced the total plate area that MNC occupied (Fig. 1C). In addition, mRNA of FP was expressed in both undifferentiated and differentiated-osteoclast (Fig. 1D). As well as $\mathrm{PGF}_{2_{\alpha}}$, FP selective agonist Fluprostenol also caused the reduction of MNC size (Fig. 1F), suggesting that $\mathrm{PGF}_{2 \alpha}$ affected to the differentiation osteoclast via FP. Because pre-osteoclasts fuse during differentiation, these results possibly suggest that $\mathrm{PGF}_{2_{\alpha}}$ inhibits pre-osteoclast cell fusion or enlargement of osteoclast via FP signaling. In fact, the number of the nuclei in MNC developed from mouse myeloid decreased clearly by $\mathrm{PGF}_{2 \alpha}$ stimulation (data not shown).

Furthermore, $\mathrm{PGF}_{2_{\alpha}}$ suppressed osteoclast-mediated bone resorption in the pit formation assay (Fig. 2C). It is known that osteoclasts grow bigger by fusion, and thereby resorb bone efficiently ${ }^{38,39}$. Therefore, $\mathrm{PGF}_{2_{\alpha}}$ possibly reduced efficiency of bone resorption by making small osteoclasts, without influencing it for accumulation of intracellular $\mathrm{H}^{+}$through V-ATPase (Fig. 1, 2).

In order to know the physiological action of $\mathrm{PGF}_{2 \alpha}$ for osteoclasts in detail, mouse RAW264, a differentiation-inducible cell line to osteoclasts, was used for analysis. The mouse cell line RAW264, a macrophage-like monocyte, can develop into osteoclast-like MNC following RANKL stimulation ${ }^{33,40}$. Differentiation to osteoclasts of RAW264 cell was induced in the presence of $\mathrm{PGF}_{2 \alpha}$, and the number and area of osteoclasts were measured. As a result, in the same result as myeloid cells, $\mathrm{PGF}_{2_{\alpha}}$ did not increase the total number of $\mathrm{MNC}$ with three or more nuclei (Fig. 3). Furthermore, $\mathrm{PGF}_{2_{\alpha}}$ suppressed osteoclast-mediated bone resorption in the pit formation assay (Fig. 4A, B). Because $\mathrm{PGF}_{2_{\alpha}}$ does not induce osteoclast apoptosis (data not shown), these decreases in pit formation were not caused by cell death, but may instead reflect a suppression of bone resorption itself by osteoclast. However, $\mathrm{PGF}_{2_{\alpha}}$ did not affect $\mathrm{H}^{+}$accumulation in lysosomes (Fig. 4C) and did not change the mRNA expression of the osteoclast-specific proteases CtpK and MMP9 (Fig. 6).

The mRNA for FP, the $\mathrm{PGF}_{2 \alpha}$ receptor, was clearly detected throughout osteoclast differentiation of RAW264 (Fig. 5A). As a fact, $\mathrm{PGF}_{2_{\alpha}}$ dose-dependently increased 
phosphorylation levels of classical PKC (PKC $\alpha$ and PKC $\left.\beta_{\mathrm{II}}\right)$ and novel PKC (PKCס), indicating that the FP signaling pathway was activated in the precense of RANKL (Fig. 5B). The classical PKC isoforms are activated by $\mathrm{Ca}^{2+}$ and DAG, novel PKCs are activated by DAG, and atypical PKCs lack binding sites for $\mathrm{Ca}^{2+}$ and $\mathrm{DAG}^{41}$. Because FP signaling increases $\mathrm{Ca}^{2+}$ and $\mathrm{DAG}, \mathrm{PGF}_{2_{\alpha}}$ play roles via FP signaling cascade in osteoclast differentiation of RAW264. $\mathrm{Ca}^{2+}$ signals could contribute to activation of the NFATc1 transcription factor, a master regulator of osteoclastic cell differentiation ${ }^{42}$. Although we predicted that FP-mediated $\mathrm{Ca}^{2+}$ increases would increase NFATc1 expression, $\mathrm{PGF}_{2 \alpha}$ did not affect expression of NFATc1 mRNA or other specific genes of osteoclast differentiation, such as CtpK and MMP9. This result supports the data that $\mathrm{PGF}_{2_{\alpha}}$ did not increase osteoclast number (Fig.1B, 3B), and further suggests that NFATc1 and other downstream genes do not contribute to decreased bone resorption by $\mathrm{PGF}_{2 \alpha}$ stimulation.

In this report, it was suggested that activation of $\mathrm{PKC}$ by $\mathrm{PGF}_{2_{\alpha}}$ might work in a suppression of bone resorption. In general, calcitonin is known as a representative molecule inhibiting bone resorption. Calcitonin inhibits bone resorption by activating signaling course through PKC, as well as signaling through PKA ${ }^{43}$. Because $\mathrm{PGF}_{2_{\alpha}}$ activates PKC course through FP receptor ${ }^{22,23}$, it is possible that $\mathrm{PGF}_{2_{\alpha}}$ inhibits bone resorption by activating calcitonin-dependent PKC signaling cascade. Calcitonin receptor is expressed only in differentiated-osteoclasts and therefore it is used for an marker gene of osteoclastic cell differentiation, however, calcitonin does not influence osteoclast cell differentiation in itself ${ }^{44}$. In addition, depression effect of bone resorption by calcitonin does not persist so that cAMP induced by calcitonin suppresses an expression of calcitonin receptor mRNA ${ }^{45,46}$ On the other hand, in contrast to calcitonin, because an expression of $\mathrm{FP}$ is not influenced at all by $\mathrm{PGF}_{2_{\alpha}}$ (Fig. 5A), inhibitory effect for bone resorption by $\mathrm{PGF}_{2_{\alpha}}$ may act continuously.

In this study, by a difference of cellular kind, reverse effect of $\mathrm{PGF}_{2_{\alpha}}$ for cellular size, miniaturization in myeloid cell and enlargement in RAW264 cell, was observed (Fig. 1B, 3B). Observation under microscope revealed that a change of the number of the nuclei was not almost found in a RAW264 cell whereas the number of the nuclei decreased by $\mathrm{PGF}_{2_{\alpha}}$ stimulation with myeloid cells clearly (data not shown). Because RAW264 cell was established by transformation with Abelson leukemia virus, c-Abl is constantly activated with an RAW cell ${ }^{40}$. This tyrosine kinase activity of c-Abl may 
have some influences on effect of $\mathrm{PGF}_{2_{\alpha}}$ to RAW264 cell. An activation of tyrosine kinase will promote cell spreading of osteoclast ${ }^{47}$, therefore, it is possible that spreading was promoted than cell miniaturization by $\mathrm{PGF}_{2 \alpha}$ in RAW264 cell.

Alternatively, decreased osteoclast area possibly resulted from differences in the cell types themselves (e.g., RAW264 vs myeloid cells), or from the influence of blood corpuscle cells not removed by the column ${ }^{48,49}$. Therefore, it is possible that indirect effect, as well as direct effect, of $\mathrm{PGF}_{2_{\alpha}}$ for an osteoclastic progenitor was observed in the column-purified myeloid cells.

Thus, $\mathrm{PGF}_{2_{\alpha}}$ acts on precursor osteoclasts or directly on osteoclasts to inhibit bone resorption. So far, it was reported that $\mathrm{PGF}_{2 \alpha}$ induced PGE2 production in the cultured-organ, but further analysis of bone-metabolic action of $\mathrm{PGF}_{2_{\alpha}}$ is required by using the living animal. Therefore, understanding the osteoclast regulatory mechanisms downstream of $\mathrm{PGF}_{2 \alpha}$ is an important future task.

\section{ACKNOWLEDGEMENTS}

This work was supported in part by Grants-in-Aid for Scientific Research from the Ministry of Education, Science, Sports, and Culture of Japan.

We wish to thank Dr. Tatsuya Takeya (Nara Institute of Science and Technology, Graduate School of Biological Sciences) for providing expression plasmid of RANKL-GFP. We are also grateful to Dr. Tsuneyoshi Sano (School of Dentistry, Showa University) for technical supporting, and to Dr. Shouji Yamada and Dr. Akiko Karakawa (School of Dentistry, Showa University) for providing cDNA of bone marrow cells. 


\section{REFERENCES}

(1) Saika, M., Inoue, D., Kido, S. and Matsumoto, T. 17 beta-estradiol stimulates expression of osteoprotegerin by a mouse stromal cell line, ST-2, via estrogen receptor-alpha. Endocrinology 142: 2205-2212. 2001.

(2) Jimi, E., Nakamura, I., Amano, H., et al. Osteoclast function is activated by osteoblastic cells through a mechanism involving cell-to-cell contact. Endocrinology 137: 2187-2190. 1996.

(3) Takahashi, N., Akatsu, T., Udagawa, N., et al. Osteoblastic cells are involved in osteoclast formation. Endocrinology 123: 2600-2602. 1988.

(4) Yasuda, H., Shima, N., Nakagawa, N., et al. Osteoclast differentiation factor is a ligand for osteoprotegerin/osteoclastogenesis-inhibitory factor and is identical to TRANCE/RANKL. Proc. Natl. Acad. Sci. USA 95: 3597-3602. 1998.

(5) Lacey, D. L., Timms, E., Tan, H. L., et al. Osteoprotegerin ligand is a cytokine that regulates osteoclast differentiation and activation. Cell 93: 165-176. 1998.

(6) Suda, T., Nakamura, I., Jimi, E. and Takahashi, N. Regulation of osteoclast function. J. Bone Miner. Res. 12: 869-879. 1997.

(7) Amano, H., Yamada, S. and Felix, R. Colony-stimulating factor-1 stimulates the fusion process in osteoclasts. J. Bone Miner. Res. 13: 846-853. 1998.

(8) Yoshida, H., Hayashi, S., Kunisada, T., et al. The murine mutation osteopetrosis is in the coding region of the macrophage colony stimulating factor gene. Nature 345: 442-444. 1990.

(9) Tanaka, S., Takahashi, N., Udagawa, N., et al. Macrophage colony-stimulating factor is indispensable for both proliferation and differentiation of osteoclast progenitors. $\mathrm{J}$. Clin. Invest. 91: 257-263. 1993. 
(10) Suda, T., Takahashi, N., Udagawa, N., Jimi, E., Gillespie, M. T. and Martin, T. J. Modulation of osteoclast differentiation and function by the new members of the tumor necrosis factor receptor and ligand families. Endocr. Rev. 20: 345-357. 1999.

(11) Fujita, D., Yamashita, N., Iita, S., Amano, H., Yamada, S. and Sakamoto, K. Prostaglandin E2 induced the differentiation of osteoclasts in mouse osteoblast-depleted bone marrow cells. Prostaglandins Leukot. Essent. Fatty Acids 68: 351-358. 2003.

(12) Kobayashi, Y., Mizoguchi, T., Take, I., Kurihara, S., Udagawa, N. and Takahashi, N. Prostaglandin E2 enhances osteoclastic differentiation of precursor cells through protein kinase A-dependent phosphorylation of TAK1. J. Biol. Chem. 280: 11395-11403. 2005.

(13) Tsuboi, K., Sugimoto, Y. and Ichikawa, A. Prostanoid receptor subtypes. Prostaglandins Other Lipid Mediat. 68-69: 535-556. 2002.

(14) Kobayashi, Y., Take, I., Yamashita, T., et al. Prostaglandin E2 receptors EP2 and EP4 are down-regulated during differentiation of mouse osteoclasts from their precursors. J. Biol. Chem. 280: 24035-24042. 2005.

(15) Tsujisawa, T., Inoue, H. and Nishihara, T. SC-19220, antagonist of prostaglandin E2 receptor EP1, inhibits osteoclastogenesis by RANKL. J. Bone Miner. Res. 20: 15-22. 2005.

(16) Chambers, T. J. and Ali, N. N. Inhibition of osteoclastic motility by prostaglandins I2, E1, E2 and 6-oxo-E1. J. Pathol. 139: 383-397. 1983.

(17) Fuller, K. and Chambers, T. J. Effect of arachidonic acid metabolites on bone resorption by isolated rat osteoclasts. J. Bone Miner. Res. 4; 209-215. 1989.

(18) Dietrich, J. W., Goodson, J. M. and Raisz, L. G. Stimulation of bone resorption by various prostaglandins in organ culture. Prostaglandins 10: 231-240. 1975. 
(19) Raisz, L. G., Alander, C. B., Fall, P. M., et al. Effect of prostaglandin $F_{2_{\alpha}}$ on bone formation and resorption in cultured neonatal mouse calvarise: Role of prostaglandin $\mathrm{E}_{2}$ production. Endocrinology 126: 1076-1079. 1990.

(20) Tokuda, H., Oiso, Y. and Kozawa, O. Protein kinase C activation amplifies prostaglandin F2 alpha-induced prostaglandin E2 synthesis in osteoblast-like cells. J. Cell. Biochem. 48: 262-268. 1992.

(21) Sugimoto, Y., Hasumoto, K., Namba, T., et al. Cloning and expression of a cDNA for mouse prostaglandin F receptor. J. Biol. Chem. 269: 1356-1360. 1994.

(22) Ito, S., Sakamoto, K., Mochizuki-Oda, N., et al. Prostaglandin F2 alpha receptor is coupled to $\mathrm{Gq}$ in cDNA-transfected Chinese hamster ovary cells. Biochem. Biophys. Res. Commun. 200: 756-762. 1994.

(23) Davis, J. S., Weakland, L. L., Weiland, D. A., Farese, R. V. and West, L. A. Prostaglandin F2 alpha stimulates phosphatidylinositol 4,5-bisphosphate hydrolysis and mobilizes intracellular $\mathrm{Ca} 2+$ in bovine luteal cells. Proc. Natl. Acad. Sci. USA. 84: 3728-3732. 1987.

(24) Takayanagi, H., Kim, S., Koga, T., et al. Induction and activation of the transcription factor NFATc1 (NFAT2) integrate RANKL signaling in terminal differentiation of osteoclasts. Dev. Cell 3: 889-901. 2002.

(25) Matsuo, K., Galson, D. L., Zhao, C., et al. Nuclear factor of activated T-cells (NFAT) rescues osteoclastogenesis in precursors lacking c-Fos. J. Biol. Chem. 279: 26475-26480. 2004.

(26) Lee, S. W., Kwak, H. B., Chung, W. J., Cheong, H., Kim, H. H. and Lee, Z. H. Participation of protein kinase $\mathrm{C}$ beta in osteoclast differentiation and function. Bone 32: 217-227. 2003.

(27) Wang, C., Steer, J. H., Joyce, D. A., Yip, K. H., Zheng, M. H. and Xu, J. 
12-O-tetradecanoylphorbol-13-acetate (TPA) inhibits osteoclastogenesis by suppressing RANKL-induced NF-kappaB activation. J. Bone Miner. Res. 18: 2159-2168. 2003.

(28) Meiyanto, E., Hoshijima, M., Ogawa, T., Ishida, N. and Takeya, T. Osteoclast differentiation factor modulates cell cycle machinery and causes a delay in s phase progression in RAW264 cells. Biochem. Biophys. Res. Commun. 282: 278-283. 2001.

(29) Ishida, N., Hayashi, K., Hoshijima, M., et al. Large scale gene expression analysis of osteoclastogenesis in vitro and elucidation of NFAT2 as a key regulator. J. Biol. Chem. 277: 41147-41156. 2002.

(30) Ly, I. A. and Mishell, R. I. Separation of mouse spleen cells by passage through columns of sephadex G-10. J. Immunol. Methods 5: 239-247. 1974.

(31) Niida, S., Kaku, M., Amano, H. Vascular endothelial growth factor can substitute for macrophage colony-stimulating factor in support of osteoclastic bone resorption. J. Exp. Med. 190: 293-298. 1999.

(32) Tanio, Y., Yamazaki, H., Kunisada, T., et al. CD9 molecule expressed on stromal cells is involved in osteoclastgenesis. Exp. Hematol. 27: 853-859. 1999.

(33) Matsumoto, M., Sudo, T., Maruyama, M., Osada, H. and Tsujimoto, M. Activation of p38 mitogen-activated protein kinase is crucial in osteoclastogenesis induced by tumor necrosis factor. FEBS Lett. 486: 23-28. 2000.

(34) Palokangas, H., Mulari, M., Vaananen, H. K. Endocytic pathway from the basal plasma membrane to the ruffled border membrane in bone-resorbing osteoclasts. J. Cell Sci. 110: 1767-1780. 1997.

(35) Henriksen, K., Gram, J., Schaller, S., et al. Characterization of osteoclasts from patients harboring a G215R mutation in $\mathrm{ClC}-7$ causing autosomal dominant osteopetrosis type II. Am. J. Pathol. 164: 1537-1545. 2004. 
(36) Abramoff, M. D., Magelhaes, P. J. and Ram, S. J. Image Processing with ImageJ. Biophotonics International 11: 36-42. 2004.

(37) Yanai, H. Statcel-The usefull add-in software forms on Excel (2nd ed). OMS, Saitama, Japan, 2004.

(38) Miyamoto, T. and Suda, T. Differentiation and function of osteoclasts. Keio J Med. 52:1-7. 2003.

(39) Yagi, M., Miyamoto, T., Sawatani, Y., et al. DC-STAMP is essential for cell-cell fusion in osteoclasts and foreign body giant cells. J. Exp. Med. 202: 345-51. 2005.

(40) Ralph, P. and Nakoinz, I. Antibody-dependent killing of erythrocyte and tumor targets by macrophage-related cell lines: enhancement by PPD and LPS. J. Immunol. 119: 950-954. 1977.

(41) Newton, A. C. Protein kinase C: structure, function, and regulation. J. Biol. Chem. 270: 28495-28498. 1995.

(42) Hirotani, H., Tuohy, N. A., Woo, J. T., Stern, P. H. and Clipstone, N. A. The calcineurin/nuclear factor of activated $\mathrm{T}$ cells signaling pathway regulates osteoclastogenesis in RAW264.7 cells. J. Biol. Chem. 279: 13984-13992. 2004.

(43) Su, Y., Chakraborty, M., Nathanson, M. H. and Barrton, R. Differential Effects of the 3', 5'-Cyclic Adenosine Monophosphate and Protein Kinase C Pathway on the Response of Isolated Rat Osteoclasts to Calcitonin. Endocrinology 131: 1497-1502. 1992.

(44) Takahashi, N., Akatsu, T., Sasaki, T., et al. Induction of calcitonin receptors by 1 alpha, 25-dihydroxyvitamin D3 in osteoclast-like multinucleated cells formed from mouse bone marrow cells. Endocrinology 123: 1504-1510. 1988.

(45) Wada, S., Udagawa, N., Akatsu, T., Nagata, N., Martin, T. J. and Findlay, D. M. 
Regulation by Calcitonin and Glucocorticoids of Calcitonin Receptor Gene Expression in Mouse Osteoclasts. Endocrinology 138: 521-529. 1997.

(46) Miyamoto, K., Nishioka, T., Waki, Y., et al. Phosphodiesterase 4 inhibitor rolipram potentiates the inhibitory effect of calcitonin on osteoclastogenesis. J. Bone Miner. Metab. 24: 260-265. 2006.

(47) Insogna, K. L., Sahni, M., Grey, A. B., et al. Colony-stimulating factor-1 induces cytoskeletal reorganization and c-src-dependent tyrosine phosphorylation of selected cellular proteins in rodent osteoclasts. J. Clin. Invest. 100:2476-85. 1997.

(48) Weitzmann, M. N., Cenci, S., Rifas, L., Haug, J., Dipersio, J. and Pacifici, R. T cell activation induces human osteoclast formation via receptor activator of nuclear factor kappaB ligand-dependent and -independent mechanisms. J. Bone Miner. Res. 16: 328-337. 2001.

(49) Kanematsu, M., Sato, T., Takai, H., Watanabe, K., Ikeda, K. and Yamada, Y. Prostaglandin E2 induces expression of receptor activator of nuclear factor-kappa B ligand/osteoprotegrin ligand on pre-B cells: implications for accelerated osteoclastogenesis in estrogen deficiency. J. Bone Miner. Res. 15: 1321-1329. 2000. 


\section{CAPTIONS TO ILLUSTRATIONS}

Fig. 1. Effect of $\mathrm{PGF}_{2_{\alpha}}$ on differentiation of the column-purified myeloid cells into osteoclast. The column-purified bone marrow cells prepared from a 6-week-old male ddY mouse were cultured with $100 \mathrm{ng} / \mathrm{mL}$ RANKL, $20 \mathrm{ng} / \mathrm{mL}$ CSF-1, and various doses of $\mathrm{PGF}_{2 \alpha}$ for $7 \mathrm{~d}$. (A) Cells were cultured with $0 \mathrm{M}$ (a), $10^{-8} \mathrm{M}$ (b), and $10^{-6} \mathrm{M}$ (c) of $\mathrm{PGF}_{2 \alpha}$, fixed with $4 \%$ paraformaldehyde solution, and stained by the TRAP method. TRAP-positive, multi-nuclear cells (MNC) were observed ( $\times 50$ magnification). (B) (C) Cells were cultured with $0 \mathrm{M}, 10^{-9} \mathrm{M}, 10^{-8} \mathrm{M}, 10^{-7} \mathrm{M}$, or $10^{-6} \mathrm{M} \mathrm{PGF}_{2 \alpha}$, and the number and area of TRAP-positive MNC with more than three nuclei were measured (cells/view). Cell size was calculated relative to size at $0 \mathrm{M}$. An error bar shows standard deviation of the mean, $n=6$. Against a value of $0 \mathrm{M}, * P<0.05$ and $* * P<$ 0.01. (D) PCR was performed using cDNA of the column-purified bone marrow cells before $(0 \mathrm{~d})$ and after $(7 \mathrm{~d})$ the induction of differentiation. (E) (F) The column-purified bone marrow cells were cultured with $0 \mathrm{M}, 10^{-9} \mathrm{M}, 10^{-8} \mathrm{M}, 10^{-7} \mathrm{M}$, or $10^{-6} \mathrm{M}$ fluprostenol, and the number and area of TRAP-positive MNC with more than three nuclei were measured (cells/view). Cell size was calculated relative to size at $0 \mathrm{M}$. An error bar shows standard deviation of the mean, $n=6$. Against a value of $0 \mathrm{M}, * P<$ 0.05 . 
Fig. 2. Effect of $\mathrm{PGF}_{2_{\alpha}}$ on bone resorption in osteoclast derived from the column-purified bone marrow cells. (A) The column-purified cells prepared from a 6-week-old male ddY mouse were cultured on dentin slices with $100 \mathrm{ng} / \mathrm{mL}$ RANKL, $20 \mathrm{ng} / \mathrm{ml} \mathrm{CSF}-1$, and various doses of $\mathrm{PGF}_{2 \alpha}$ for $7 \mathrm{~d}$, and then for another $2 \mathrm{~d}$ to induce pit formation. Cells were cultured with $0 \mathrm{M}(\mathrm{a}), 10^{-8} \mathrm{M}(\mathrm{b})$, and $10^{-6} \mathrm{M}$ (c) $\mathrm{PGF}_{2 \alpha}$, and dentin slices were treated as described in the Materials and Methods for observation under an electron microscope $(\times 20)$. (B) Cells were cultured on dentin slices with $0 \mathrm{M}$, $10^{-9} \mathrm{M}, 10^{-8} \mathrm{M}, 10^{-7} \mathrm{M}$, and $10^{-6} \mathrm{M}$ of $\mathrm{PGF}_{2_{\alpha}}$. After culturing, the pit area was measured using image analysis software (ImageJ), and the ratios of total pit area are compared. An error bar shows standard deviation of the mean, $n=3$. (C) Cells were cultured with 100 ng/mL RANKL, $20 \mathrm{ng} / \mathrm{mL}$ CSF-1, and $0 \mathrm{M}$ (a) or $10^{-6} \mathrm{M}$ (b) $\mathrm{PGF}_{2_{\alpha}}$ for $7 \mathrm{~d}$, and then stained by acridine orange. Stained cells were observed under a fluorescence microscope $(\times 50)$. 
Fig. 3. Effect of $\mathrm{PGF}_{2 \alpha}$ on differentiation of RAW264 cell into osteoclast. RAW264 cells were cultured in the presence of $100 \mathrm{ng} / \mathrm{mL}$ RANKL and various doses of $\mathrm{PGF}_{2_{\alpha}}$ for $5 \mathrm{~d}$. (A) Cells were cultured with $0 \mathrm{M}$ (a), $10^{-8} \mathrm{M}$ (b), and $10^{-6} \mathrm{M}$ (c) of $\mathrm{PGF}_{2 \alpha}$, fixed with $4 \%$ paraformaldehyde solution, and stained by the TRAP method. TRAP-positive MNC observed under microscope are indicated $(\times 50)$. (B) (C) Cells were cultured with $0 \mathrm{M}, 10^{-9} \mathrm{M}, 10^{-8} \mathrm{M}, 10^{-7}$, and $10^{-6} \mathrm{M}$ of $\mathrm{PGF}_{2 \alpha}$, and the number and area of TRAP-positive MNC with more than three nuclei were measured (cells/view). Cell size is calculated relative to $0 \mathrm{M}$. An error bar shows standard deviation of the mean, $n=5$. Against a value of $0 \mathrm{M}, * *$ indicates $P<0.01$. 
Fig. 4. Effect of $\mathrm{PGF}_{2 \alpha}$ on bone resorption of osteoclast derived from RAW264 cell. (A) RAW264 cells were cultured on dentin slices in the presence of $100 \mathrm{ng} / \mathrm{mL}$ RANKL and various doses of $\mathrm{PGF}_{2 \alpha}$ for $5 \mathrm{~d}$. Cells were then cultured for a further $6 \mathrm{~d}$ to induce pit formation. Cells were cultured with $0 \mathrm{M}(\mathrm{a}), 10^{-8} \mathrm{M}(\mathrm{b})$, and $10^{-6} \mathrm{M}(\mathrm{c})$ of $\mathrm{PGF}_{2 \alpha}$, and then dentin slices were treated as described in Materials and Methods for observation under a scanning electron microscope $(\times 20)$. (B) Cells were cultured on dentin slices with $0 \mathrm{M}, 10^{-9} \mathrm{M}, 10^{-8} \mathrm{M}, 10^{-7} \mathrm{M}$, and $10^{-6} \mathrm{M}$ of $\mathrm{PGF}_{2_{\alpha}}$. After culture, the area of pit was measured using image analysis software (ImageJ), and the ratio of the total pit area was compared. An error bar shows standard deviation of the mean, $n=3$. Against a value of $0 \mathrm{M}, * P<0.05$. (C) RAW264 cells were cultured with $100 \mathrm{ng} / \mathrm{mL}$ RANKL and with $0 \mathrm{M}$ (a) or $10^{-6} \mathrm{M}$ (b) of $\mathrm{PGF}_{2 \alpha}$ for $5 \mathrm{~d}$, and then stained by acridine orange. Stained cells were observed under a fluorescence microscope $(\times 50)$. 
Fig. 5. Activation of FP signaling by stimulation with $\mathrm{PGF}_{2_{\alpha}}$. (A) RAW264 cells were cultured with RANKL ((-) $0 \mathrm{ng} / \mathrm{mL},(+) 100 \mathrm{ng} / \mathrm{mL})$ and $\mathrm{PGF}_{2_{\alpha}}\left((-) 0 \mathrm{M},(+) 10^{-8} \mathrm{M}\right)$, and then total RNA was prepared for RT-PCR. PCR was performed with FP-specific primers (40 cycles), or G3PDH-specific primers (20 cycles). (B) RAW264 cells were cultured for $24 \mathrm{~h}$ with RANKL ((-) $0 \mathrm{ng} / \mathrm{mL},(+) 100 \mathrm{ng} / \mathrm{mL})$. Cells were then cultured with $\mathrm{PGF}_{2_{\alpha}}\left(0 \mathrm{M}, 10^{-8} \mathrm{M}, 10^{-6} \mathrm{M}\right)$ or $100 \mathrm{nM}$ TPA for $30 \mathrm{~min}$ and subjected to Western blot analysis. 
Fig. 6. Expression of osteoclast-specific genes. RAW264 cells were cultured with $100 \mathrm{ng} / \mathrm{mL}$ RANKL and with $0 \mathrm{M}, 10^{-8} \mathrm{M}$ or $10^{-6} \mathrm{M} \mathrm{PGF}_{2_{\alpha}}$ for $1,3,5$, or $7 \mathrm{~d}$. Total RNA was extracted for RT-PCR with specific primers for CtpK (22 cycles), TRAP (22 cycles), CtR (32 cycles), MMP9 (32 cycles), NFATc1 (20 cycles), RANK (30 cycle) and G3PDH (18 cycles). CtpK, cathepsin K; CtR, calcitonin receptor; TRAP, tartrate-resistant acid phosphatase; MMP9, matrix metalloproteinase 9; NFATc1, nuclear factor of activated T cell c1; RANK, Receptor activator of nuclear factor $\kappa \mathrm{B}$. 
Fig. 1

A (a)

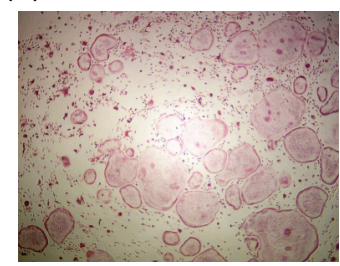

B

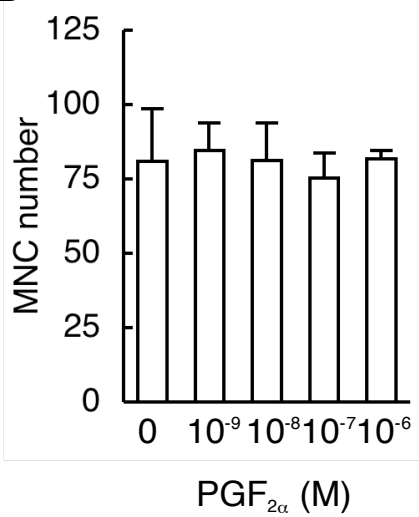

E

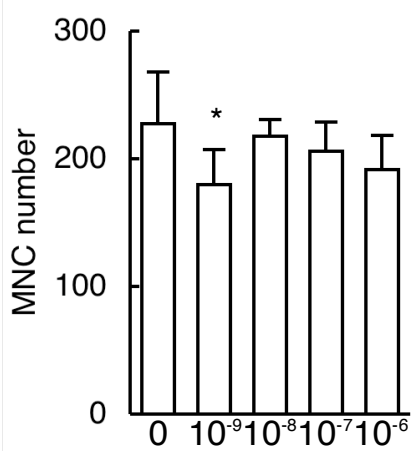

Fluprostenol (M) (b)

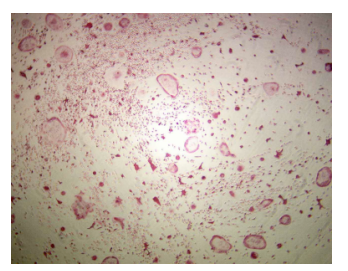

C

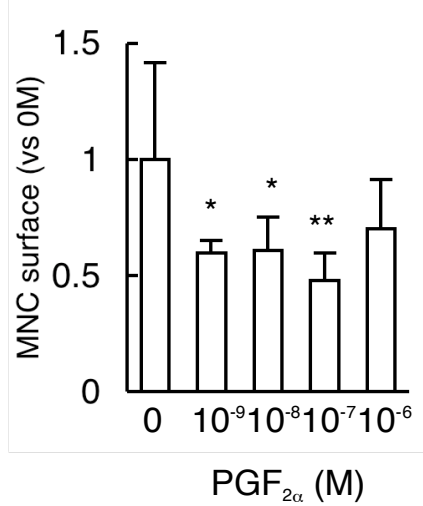

F

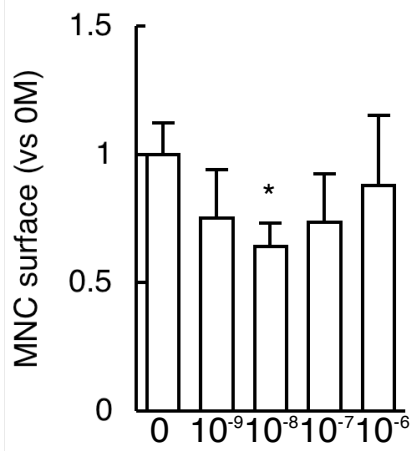

Fluprostenol (M) (c)

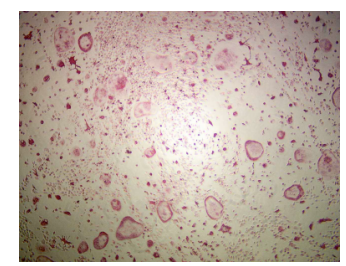

D

- - FP

$--\mathrm{G} 3 \mathrm{PDH}$ 
Fig. 2

A (a)

(b)

(c)
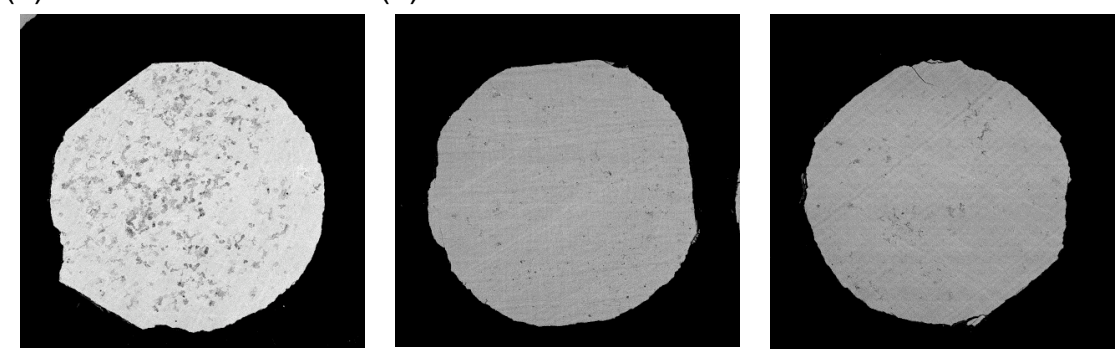

B

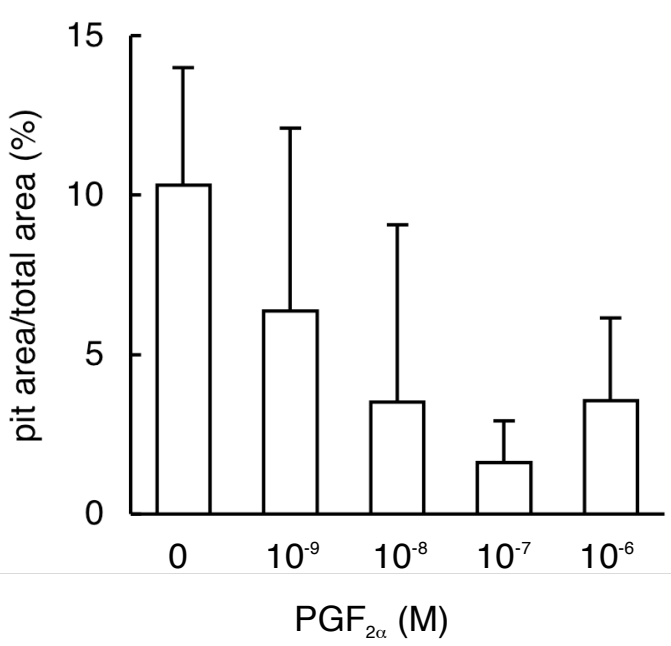

C (a)

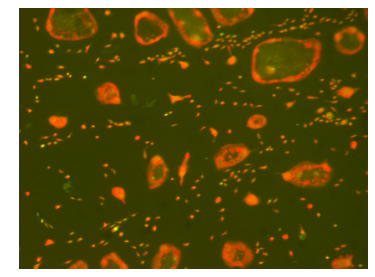

(b)

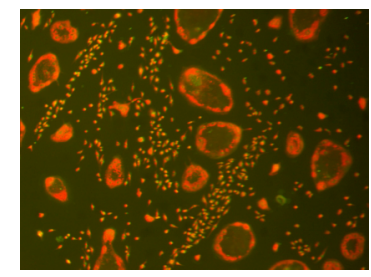


Fig. 3

A (a)

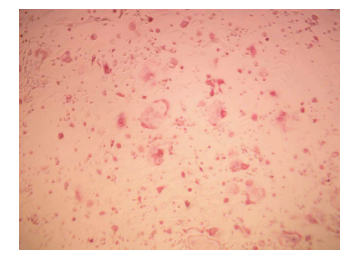

B

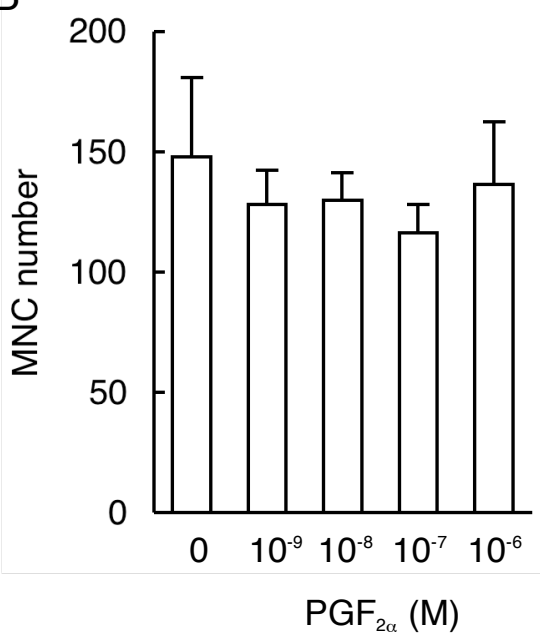

(c)
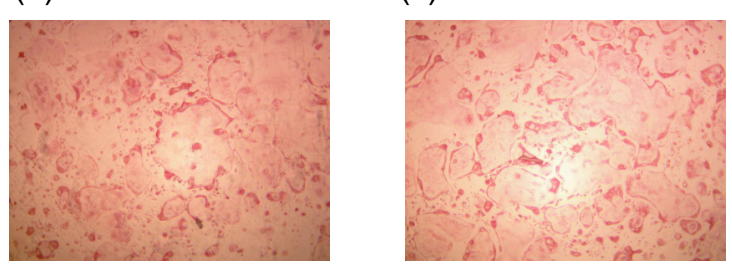

C

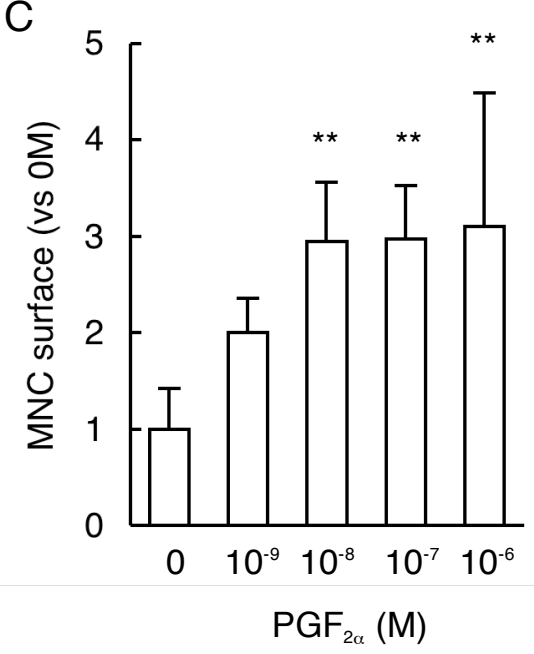


Fig. 4

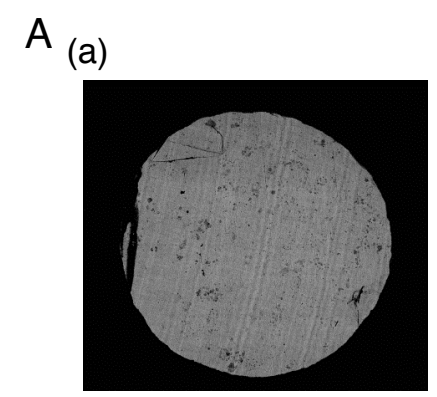

(b)

(c)

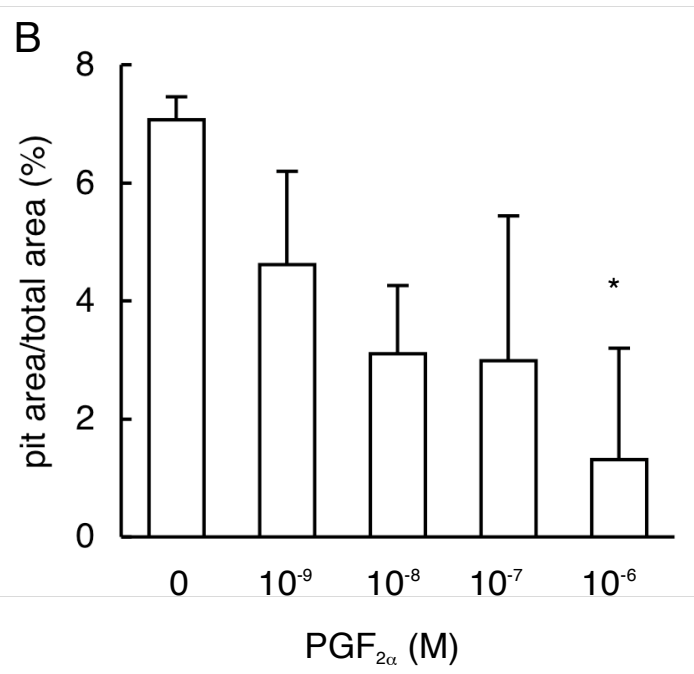

C (a)

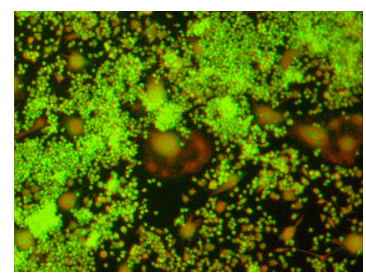

(b)

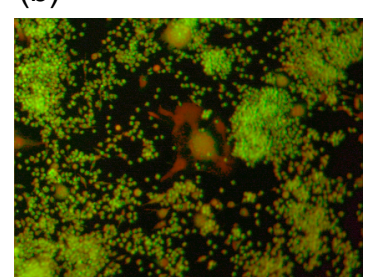


Fig. 5

A

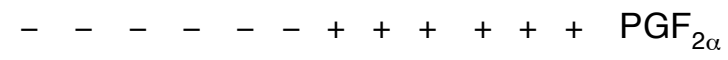

$-\ldots+++\ldots+++$ RANKL

FP $\quad \begin{array}{llllllllllll}1 & 5 & 11 & 1 & 5 & 11 & 1 & 5 & 11 & 1 & 5 & 11 \text { (day) }\end{array}$

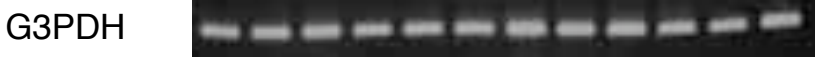

B

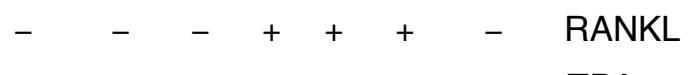

WB:

$-\quad-\quad-\quad-\quad+$ TPA

p-PKC(pan)

$\begin{array}{llllllll}0 & 10^{-8} & 10^{-6} & 0 & 10^{-8} & 10^{-6} & 0 & \mathrm{PGF}_{2 \alpha}(\mathrm{M})\end{array}$

$\mathrm{p}-\mathrm{PKC} \alpha / \beta_{\|}$

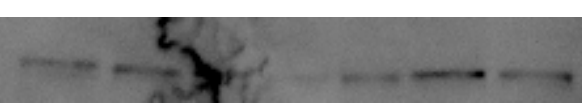

p-PKC $\delta$

$\beta-$ Actin 
Fig. 6

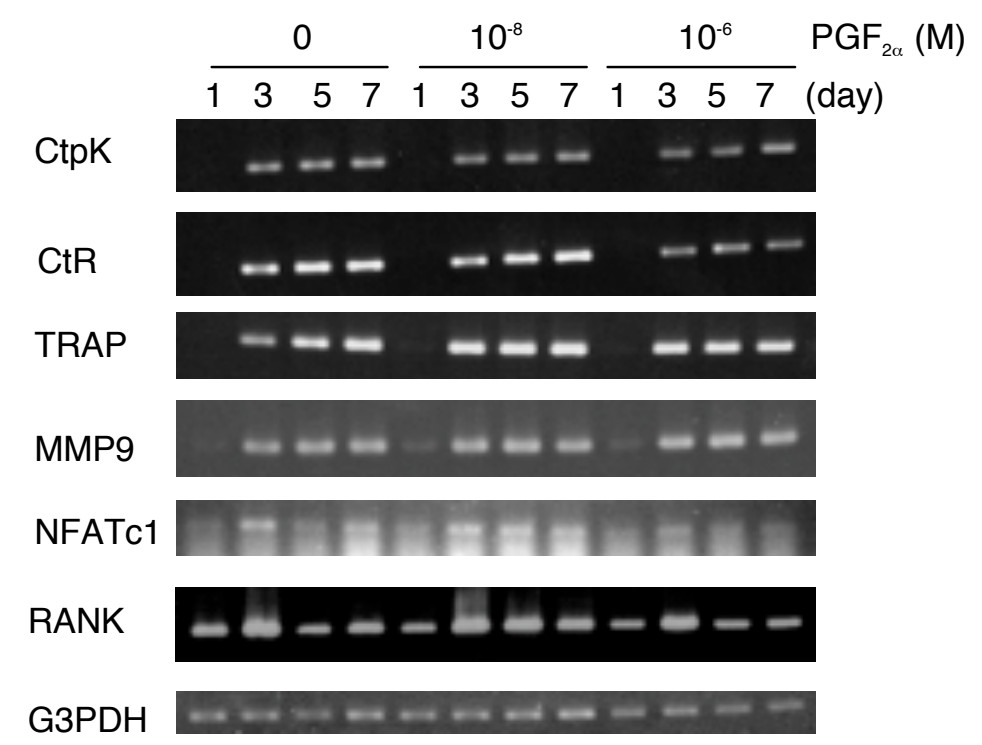


Fig. S1

A (a)

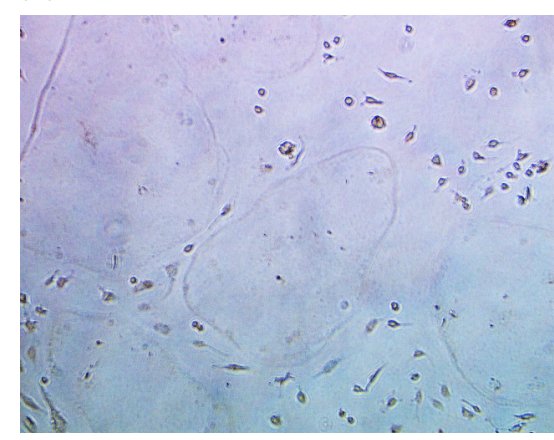

B (a)

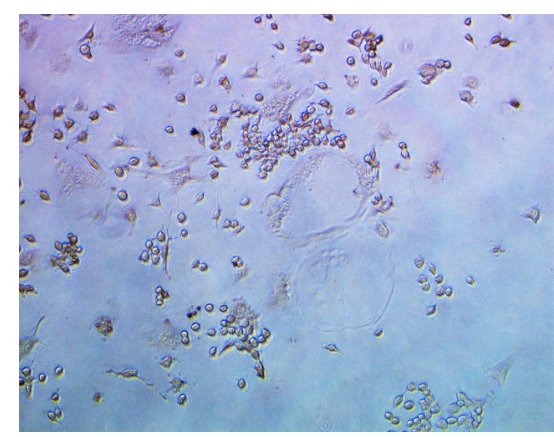

(b)

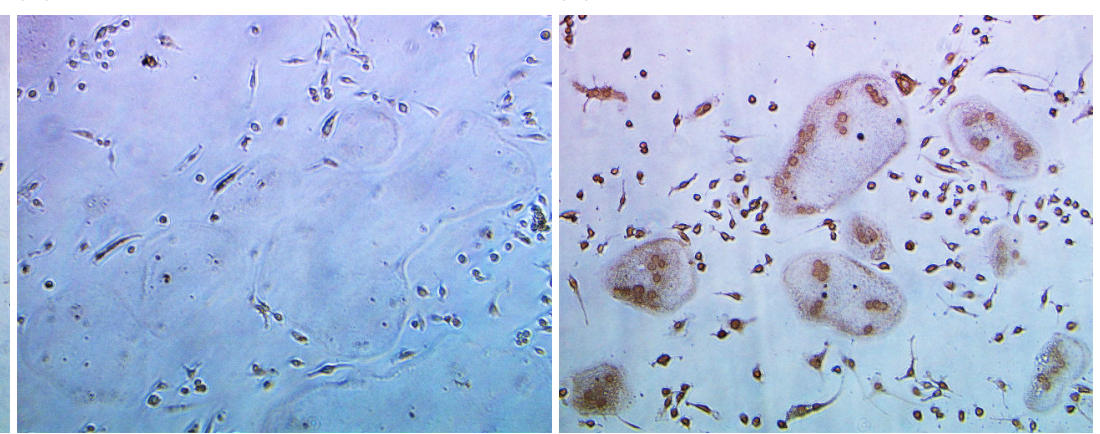

(b)

(c)

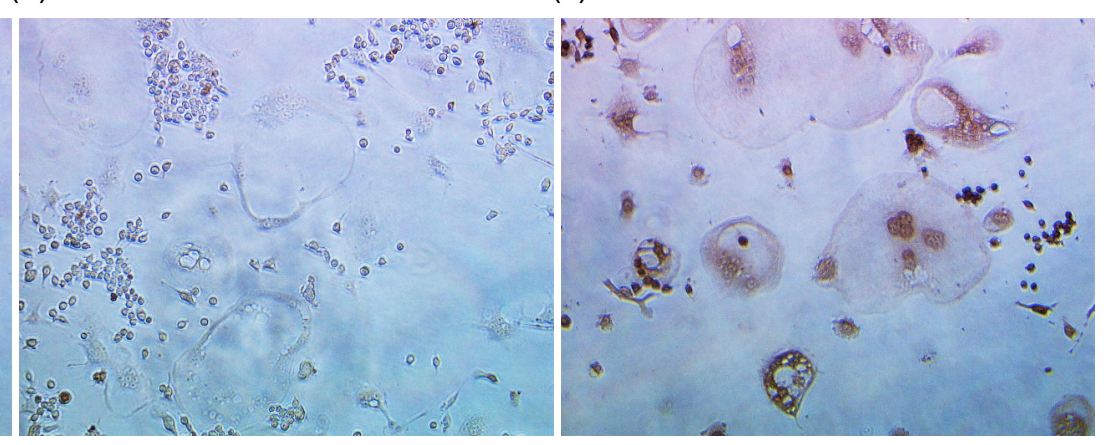

Fig. S1 PGF Pa $_{2}$ did not induce apoptosis in osteoclastgenesis. (A) The column-purified bone marrow cells prepared from a 6-week-old male ddY mouse were cultured with $100 \mathrm{ng} / \mathrm{mL}$ RANKL, $20 \mathrm{ng} / \mathrm{mL}$ CSF-1, and various doses of $\mathrm{PGF}_{2 \alpha}$ for $6 \mathrm{~d}$. Cells were cultured with $0 \mathrm{M}\left(\mathrm{a}, \mathrm{c}\right.$ ) and $10^{-6} \mathrm{M}(\mathrm{b})$ of PGF2a, and stained by the ApopTag ${ }^{\circledR}$ Plus Peroxidase In Situ Apoptosis detection Kit (CHEMICON, Billerica, MA, USA). A positive control sample was prepared by treating DNase I (c). Apoptosisnegative, multi-nuclear cells (MNC) were observed ( $\times 400$ magnification). (B) RAW264 cells were cultured with $100 \mathrm{ng} / \mathrm{mL}$ RANKL and various doses of $\mathrm{PGF}_{2 \alpha}$ for $4 \mathrm{~d}$. Cells were cultured with $0 \mathrm{M}$ (a, c) and $10^{-6} \mathrm{M}(\mathrm{b})$ of PGF2a, and stained by the ApopTag ${ }^{\circledR}$ Plus Peroxidase In Situ Apoptosis detection Kit. A positive control sample was prepared by treating DNase I (c). Apoptosis-negative, multi-nuclear cells (MNC) were observed (×400 magnification). 